\title{
Kinetics of crystals growth under electron-beam crystallization of amorphous films of hafnium dioxide
}

\author{
A.G.Bagmut, I.A.Bagmut \\ NTU "KhPI", 2 Kyrpychova Str., 61002 Kharkiv, Ukraine
}

Received February 21, 2018

\begin{abstract}
Amorphous films of $\mathrm{HfO}_{2}$ are prepared by laser ablation of $\mathrm{Hf}$ target in an oxygen atmosphere. Its crystallization was performed under the electron beam impact in a column of electron microscope. Formation and growth of $\mathrm{HfO}_{2}$ crystals are investigated "in situ". The transformation kinetic curves are plotted on the basis of a frame-by-frame analysis of the video recorded flick during the film crystallization. According to the structural and morphological features, the phase transformation corresponds to the dendrite polymorph crystallization and can be either single-stage or two-stage in nature. In the latter case, the size-phase effect takes place, consisting in the fact, that when the crystal of orthorhombic modification of $\mathrm{HfO}_{2}$ reaches a critical size $(\sim 0.2 \mu \mathrm{m})$, it splits into domains with orthorhombic and monoclinic crystal lattices. The kinetic parameters of the crystallization are determined and it is shown, that the quadratic dependence of the fraction of the crystalline phase on time takes place. The average value of the relative length for the dendrite polymorphic crystallization is about 3075 . The phase transition from the amorphous state to the crystalline one is accompanied by increasing of the relative density of matter of the film by about $2.5 \%$. The crystallized film consists predominantly of dendrites of the monoclinic modification of $\mathrm{HfO}_{2}$.
\end{abstract}

Keywords: kinetic of phase transformation, in situ TEM, electron irradiation, dendrites, hafnium dioxide, amorphous films.

Аморфные пленки $\mathrm{HfO}_{2}$ получены лазерной абляцией мишени $\mathrm{Hf}$ в атмосфере кислорода. Их кристаллизацию осуществляли воздействием электронного луча в колонне электронного микроскопа. Образование и рост кристаллов $\mathrm{HfO}_{2}$ исследован "на месте". Кинетические кривые превращения построены на основе покадрового анализа видеофильма процесса кристаллизации пленки. По структурно-морфологическим признакам фазовое превращение соответствует дендритной полиморфной кристаллизации и может носить как одностадийный, так и двустадийный характер. В последнем случае имеет место размернофазовый әффект, состоящий в том, что когда размер кристалла орторомбической модификации $\mathrm{HfO}_{2}$ превышает критическую величину ( 0.2 мкм), то он расщепляется на домены, которые имеют как орторомбическую, так и моноклинную кристаллическую решетку. Определены кинетические параметры кристаллизации и показано, что имеет место квадратичная зависимость доли кристаллической фазы от времени. Среднее значение относительной длины при дендритной полиморфной кристаллизации составляет 3075. Фазовое превращение из аморфного в кристаллическое состояние сопровождается увеличением относительной плотности вещества пленки на $~ 2.5 \%$. После полной кристаллизации пленка состоит преимущественно из дендритов моноклинной модификации $\mathrm{HfO}_{2}$. 
Кінетика росту кристалів під час електронно-променевої кристалізації аморфних плівок діоксиду гафнію. О.Г.Багмут, І.О.Багмут.

Аморфні плівки $\mathrm{HfO}_{2}$ отримано лазерною абляцією мішені $\mathrm{Hf}$ в атмосфері кисню. Їх кристалізацію здійснювали впливом електронного променя у колоні електронного мікроскопа. Формування і зростання кристалів $\mathrm{HfO}_{2}$ досліджено "на місці". Кінетичні криві перетворення побудовано на основі покадрового аналізу відеофільму процесу кристалізації плівки. За структурно-морфологічними ознаками фазове перетворення відповідає дендритній поліморфній кристалізації і може носити як одностадійний, так i двостадійний характер. В останньому випадку має місце розмірно-фазовий ефект, який полягає у тому, що коли розмір кристала орторомбічної модифікації $\mathrm{HfO}_{2}$ перевищує критичну величину ( 0.2 мкм), то він розщеплюється на домени, які мають як орторомбічну, так і моноклінну кришталеву гратку. Визначено кінетичні параметри кристалізації і показано, що має місце квадратична залежність частки кристалічної фази від часу. Середнє значення відносної довжини при дендритній поліморфній кристалізації складає 3075. Фазове перетворення з аморфного стану у кристалічний стан супроводжується збільшенням відносної щільності речовини плівки на $2.5 \%$. Після повної кристалізації плівка складається переважно з дендритів моноклінної модифікації $\mathrm{HfO}_{2}$.

\section{Introduction}

Hafnium dioxide $\left(\mathrm{HfO}_{2}\right)$ in thin film state attracts significant interest owing to their high values of its dielectric constant, refractive index, neutron absorption cross section, and also thermal stability (melting point $\sim 2800^{\circ} \mathrm{C}$ ) [1]. Besides this amorphous gate insulators are more preferred than the crystalline one since they can effectively reduce the problems, arising from the crystal orientation, grain boundary, and the lattice mismatch at the interfaces [2]. Amorphous films of $\mathrm{HfO}_{2}$ can be prepared with different methods: atomic layer deposition [3], chemical vapor deposition [4], ion-plasma sputtering of $\mathrm{HfO}_{2}$ targets [5] and others.

Method of pulsed laser deposition (PLD) also finds a wide application in production of the films and coatings of $\mathrm{HfO}_{2}$. Laser ablation of hafnium dioxide leads to formation on the substrate of a layer, consisting of tetragonal and cubic $\mathrm{HfO}_{2}$ nanoparticles, having a spherical shape and sizes from 10 to $100 \mathrm{~nm}$ [6]. Method of pulsed laser evaporation of hafnium target in an oxygen atmosphere leads to formation on the substrate of amorphous layer of $\mathrm{HfO}_{2}$ at room temperature $[7,8]$.

Electron-beam crystallization of the amorphous $\mathrm{HfO}_{2}$ is accompanied by formation of dendrites crystals. The dendrites are formed both from the embryos of $\mathrm{HfO}_{2}$ monoclinic modification, and from the embryos of $\mathrm{HfO}_{2}$ orthorhombic modification. In the latter case, the dimension-phase effect takes place [8]. It manifests itself in the fact, that when the $\mathrm{HfO}_{2}$ crystal of orthorhombic modification reaches a critical size $(\sim 0.2 \mu \mathrm{m})$, the domains of the monoclinic modification of $\mathrm{HfO}_{2}$ are formed in it. Therefore, at the final stage of the film crystallization, the dominant component is the monoclinic phase represented by the dendrites of $\mathrm{HfO}_{2}$ crystals.

"In-situ" transmitting electron microscopy is an effective method for studying the structural, morphological and kinetic features of the phase transition from the amorphous to crystalline state in thin films [9, 10]. This method makes it possible to determine both the structural and morphological changes and the numerical values of the relative change in density and the kinetic parameters of the substance crystallization. Based on the results of the electron microscopic investigations and analysis of the data available in the literature, classification of the types of crystallization of amorphous films in accordance with their structural and morphological features was proposed in $[11,12]$. According to this classification, the following types of crystallization modes are distinguished: the layer (LPC), island (IPC), and dendrite (DPC) polymorphic crystallizations, as well as the fluid-phase crystallization (FPC) accompanied by the medium separation.

Quantitative data on morphology and kinetics of crystallization of the films are important for predicting of the stability and properties of the amorphous components of electronic devices. Such data are not available for amorphous $\mathrm{HfO}_{2}$. Therefore, the aim of this work was to obtain the amorphous $\mathrm{HfO}_{2}$ films by PLD method, to study their structure, morphology and kinetics of the electron-beam crystallization. 


\section{Experimental}

Films of $\mathrm{HfO}_{2}$ were prepared by PLD technique in oxygen atmosphere at pressure of $0.13 \mathrm{~Pa}$. Sputtering of a high-purity hafnium target was carried out with the use of pulsed laser radiation from an LTI-PCh-5 laser operating in the Q-switched mode. The laser target erosion products were deposited on $\mathrm{KCl}(001)$ substrates at the room temperature. Thickness of the films varied in the range from 25 to $30 \mathrm{~nm}$. Details of the pulsed laser deposition technique were described in $[13,14]$. Crystallization of the film was initiated by electron beam irradiation in a column of transmission electron microscope at the beam current of $\sim 20 \mu \mathrm{A}$. The crystallization rate was controlled by varying the density $j$ of the electron current through the sample, which was varied in the range from 1.1 to $6.5 \mathrm{~A} \cdot \mathrm{mm}^{-2}$ depending on the electron beam focusing.

Phase and structural analysis was performed using the electron diffraction and transmission electron microscopy methods. The film crystallization process was registered in the video recording mode at a frame rate of $30 \mathrm{~s}^{-1}[15,16]$. Data on the kinetics of the crystallization process were obtained from the analysis of individual frames of the video recorded "in situ" at a fixed tangential crystal growth rate $v$ (specified by the electron current density $j$ ), which is determined by the following relationship:

$$
v=\frac{\Delta D}{\Delta t}
$$

where $\Delta D$ is the increment in the average value of diameter $D$ of $\mathrm{HfO}_{2}$ microcrystal during a time period $\Delta t$ between the two video frames corresponding to the moments of the recording $t$ and $t+\Delta t$. The crystals size was determined from the contrast of the electron microscopy image, because it was different from the contrast of the electron microscopy image of the amorphous matrix.

The relative change $\gamma$ in density $\rho$ of the material of the film after its crystallization [10] was determined according to (2):

$$
\gamma=\frac{\rho_{c}-\rho_{a}}{\rho_{a}}=\left(\frac{L_{a}}{L_{c}}\right)^{3}-1,
$$

where $\rho_{c}$ and $\rho_{a}$ are the material densities in the crystalline and amorphous states, respectively, and $L_{a}$ and $L_{c}$ are the distances between fixed marks in the same region of the images before and after films crystallization. The marks were the solidified micro droplets of the melt of $\mathrm{Hf}$ (the spraying effect).

\section{Results and discussion}

The PLD of $\mathrm{Hf}$ in oxygen atmosphere resulted in formation of the amorphous $\mathrm{HfO}_{2}$ films on substrate at the room temperature. Electron-beam crystallization of the film leads to formation of $\mathrm{HfO}_{2}$ crystals with different structure and morphology.

Fig. 1a shows an electron microscopic image, illustrating the beginning of crystallization of the amorphous phase. Crystal 1 has pronounced dendrite morphology, which manifests itself in the presence of branches of the first and second order. Studies have shown that such crystals have a monoclinic crystal lattice and during their growth its structure and dendrite morphology do not change. Crystal 2 has a disk-like shape. The selected area electron diffraction (SAED) pattern of this crystal is shown in Fig. 1b. The results obtained by interpreting of this SAED pattern show that this is an orthorhombic modification of hafnium dioxide. Crystals with a number 2 in Fig. 1a and $1 c$ have the orthorhombic lattice. In the process of its growth, when their diameter $D$ exceeds the critical value $D^{*}$, the polymorphic transformation occurs to the monoclinic modification of $\mathrm{HfO}_{2}$. It is accompanied by the formation of domains with the monoclinic crystal lattice within the discshaped crystal of $\mathrm{HfO}_{2}$.

Fig. 1c shows a bright-field electron microscopic image of the disc-shaped crystals (numbered as 2), whose diameter is less than $D^{*}$. The crystal with a dark contrast is in a reflective position. The crystallites, numbered as 3 , have diameter $D>D^{*}$. They consist of domains of the orthorhombic and monoclinic modifications of $\mathrm{HfO}_{2}$.

The SAED pattern of one of these crystallites, containing reflexes of both the original orthorhombic modification ("or" indices) and the new monoclinic modification (" $m$ " indices), is shown in Fig. 1d. The inset in the right upper corner of Fig. 1c corresponds to the dark-field image of this crystal in the light of the reflection $(\mathrm{T12})_{\text {or }}$. The domains of orthorhombic modification have $[\mathrm{T11}]_{o r}$ zone axis, and domains of the monoclinic modification have $[1 \mathrm{T0}]_{m}$ zone axis. In this case, between the domains of both types, the orientation relation is fulfilled:

$$
(30 \overline{3})_{o r}[\overline{1} 1 \overline{1}]_{o r} \bumpeq /(\overline{223})_{m}[1 \overline{1} 0]_{m} \text {. }
$$



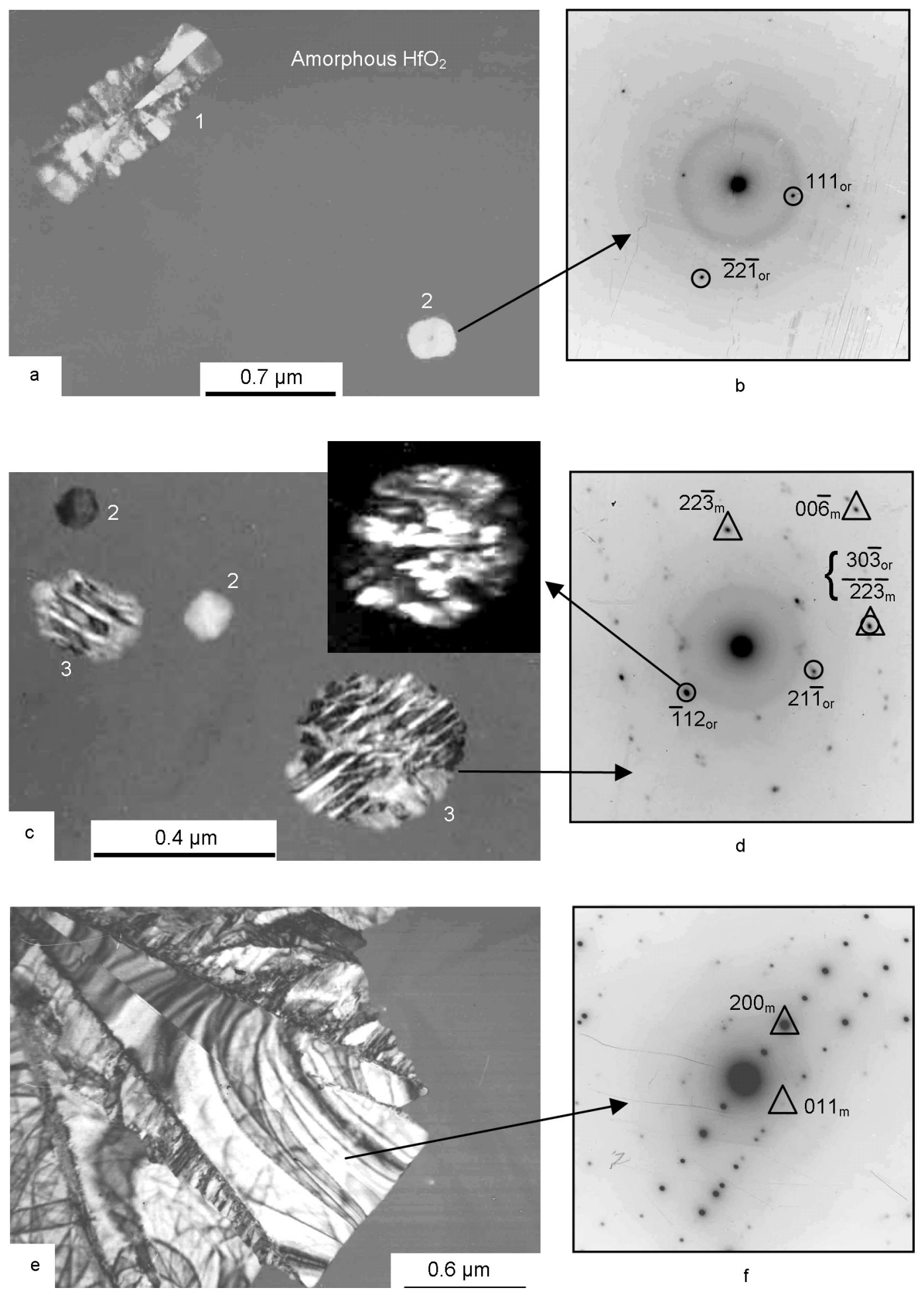

Fig. 1. "In situ" electron-beam crystallization of amorphous film of $\mathrm{HfO}_{2}$. (a) Electron microscope images of dendrite (1) and disc-like (2) crystals of $\mathrm{HfO}_{2}$. (b) The SAED pattern of the disc-like crystal (2), containing reflexes of orthorhombic modification of $\mathrm{HfO}_{2}$. (c) Electron microscope images of disc-like crystals of $\mathrm{HfO}_{2}$ with size smaller than the critical (2) and crystallites with size larger than the critical (3). The inset in the right upper corner corresponds to dark-field image of the crystallite (3) in the light of reflection (112) or. (d). The SAED pattern of the crystallite (3), containing reflexes of orthorhombic and of monoclinic modification of $\mathrm{HfO}_{2}$. (e) Dendrite branches and SAED pattern of the first-order dendrite branch (f). Contrast on the SAED patterns is inverted. 

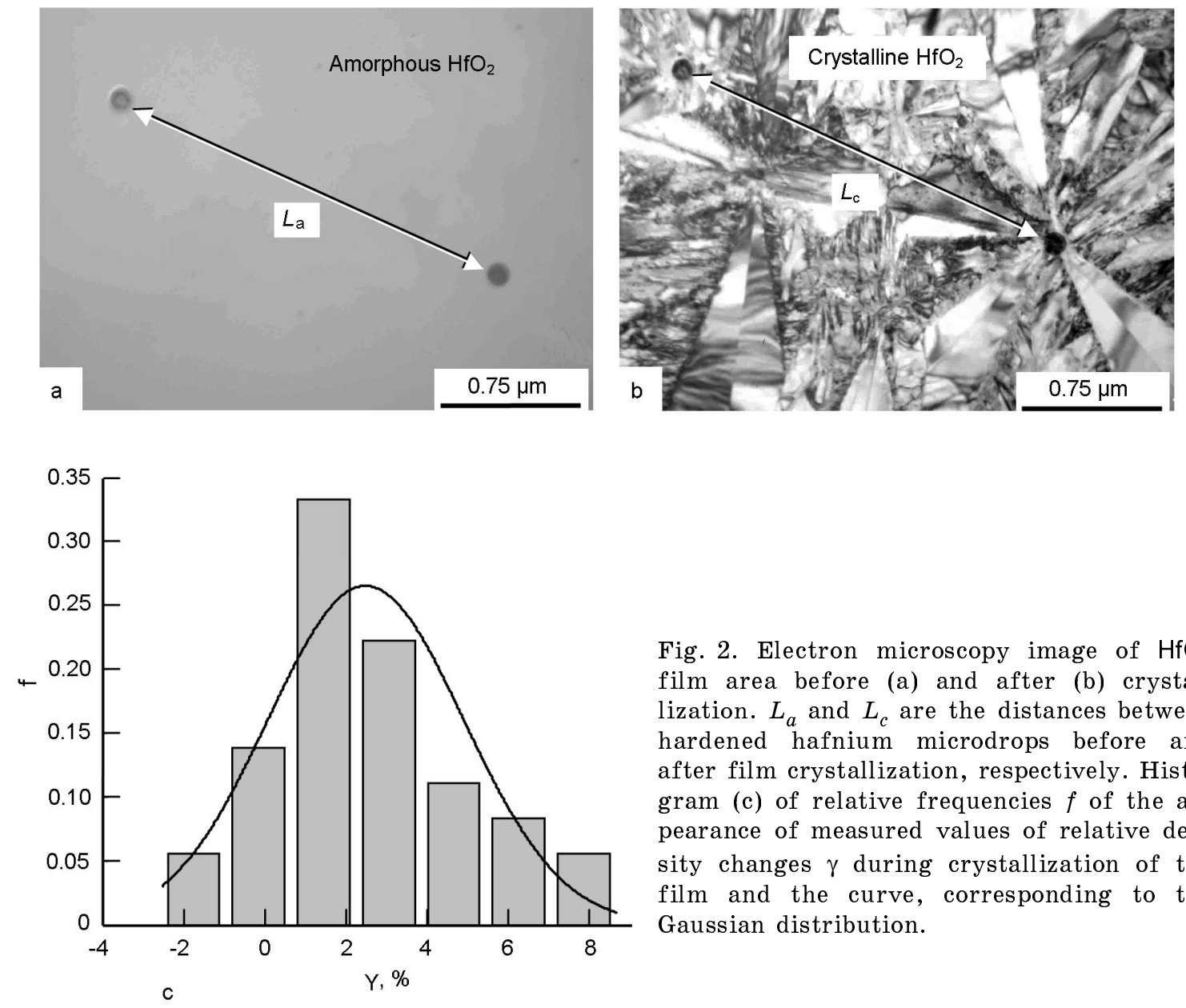

Fig. 2. Electron microscopy image of $\mathrm{HfO}_{2}$ film area before (a) and after (b) crystallization. $L_{a}$ and $L_{c}$ are the distances between hardened hafnium microdrops before and after film crystallization, respectively. Histogram (c) of relative frequencies $f$ of the appearance of measured values of relative density changes $\gamma$ during crystallization of the film and the curve, corresponding to the Gaussian distribution.

As crystallites grow, they acquire the dendrite morphology with branches of the first, second and higher orders, which have monoclinic lattice of $\mathrm{HfO}_{2}$ (Fig. 1e). The SAED pattern of the first-order dendrite branch is shown in Fig. 1f. The results obtained by interpreting of this SAED pattern showed that this is monoclinic modification of $\mathrm{HfO}_{2}$. The zone axis of this crystal is directed along $[01 \overline{1}\}]_{m}$.

The relative change of the density during crystallization of amorphous $\mathrm{HfO}_{2}$ was analyzed using relation (2). Figure 2 shows the electron microscopy image of the $\mathrm{HfO}_{2}$ film area before (a) and after (b) its complete crystallization. $L_{a}$ and $L_{c}$ are the distances between hardened $\mathrm{Hf}$ micro drops before and after film crystallization, respectively. The results of statistical treatment of measured relative density changes $\gamma$ during the amorphous $\mathrm{HfO}_{2}$ crystallization are shown in the form of frequency histograms in Fig. 2c. The $\gamma$ distribution is characterized by the corrected root-mean-square deviation of $2.41 \%$, the positive asymmetry of 0.45 , and the positive excess of 3.14. For com- parison, Fig. 2c also shows the $\gamma$ curve corresponding to the Gaussian distribution. At the reliability level of 0.5 , the relative density change during hafnium dioxide film crystallization $\gamma=2.51 \pm 1.66 \%$. Hence, the growing microcrystal from the time of its nucleation and during growth is continuously subjected to tensile stresses from the side of the amorphous matrix, which can be a cause of one of the reasons for the development of the dendrite morphology of crystalline $\mathrm{HfO}_{2}$.

The one-stage phase transformation in the amorphous film is accompanied by nucleation and growth of crystallite in the form of dendrites of the monoclinic modification of $\mathrm{HfO}_{2}$, similar to dendrite 1 in Fig. 1a. The dependences of the average diameter $D$ of the dendrites on time $t$ for various growth rates are shown in Fig. 3a. Straight lines are constructed from the measurement data of $D$ using the least squares method. The linear dependence $D(t)$ indicates on the constancy of the growth rate $v$ of each dendrite crystallite at a fixed electron current density through the sample. The value of $v$ 

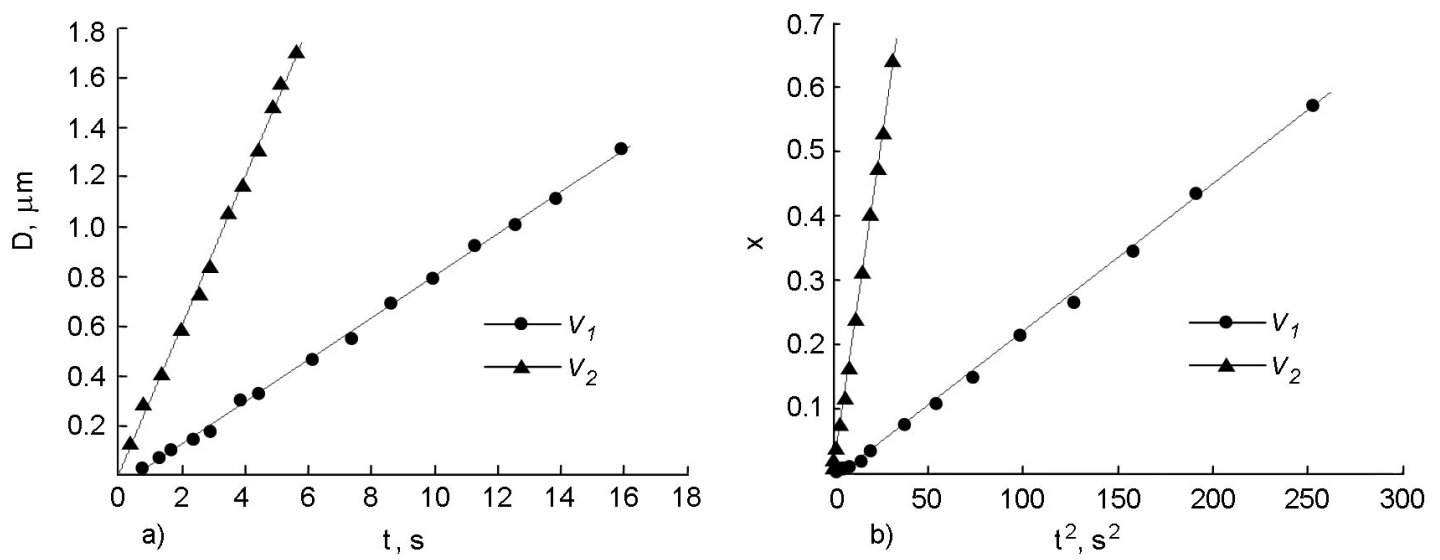

Fig. 3. Kinetics of single-stage crystallization of $\mathrm{HfO}_{2}$. Dependences of the average diameter $D$ of dendrites on time $t$ (a) and dependences of the fraction of the crystalline phase $x$ on $t^{2}$ (b) for various growth rates: $v_{1}=0.084 \mu \mathrm{m} \cdot \mathrm{s}^{-1} ; v_{2}=0.299 \mu \mathrm{m} \cdot \mathrm{s}^{-1}$.

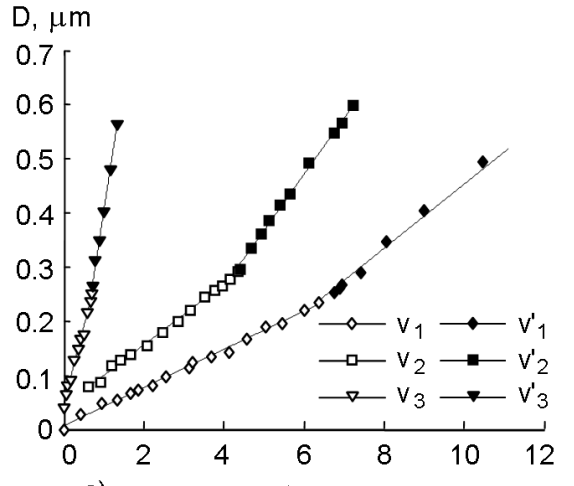

a)

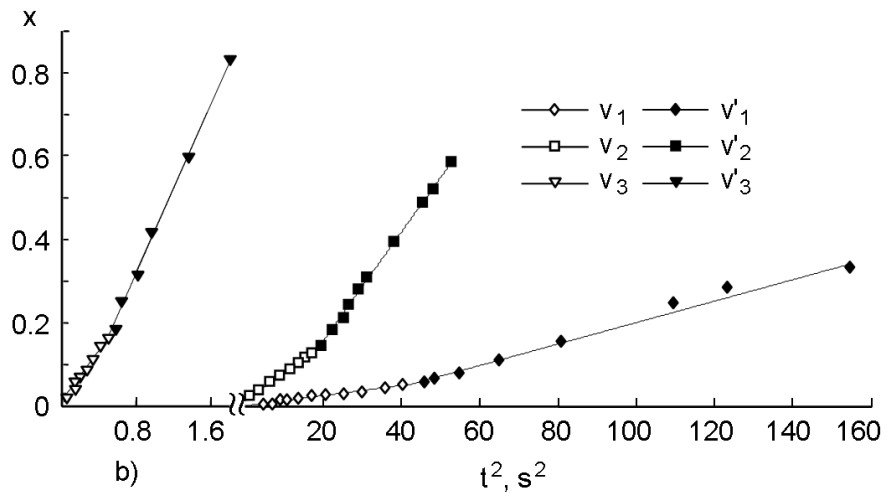

Fig. 4. Kinetics of two-stage crystallization of $\mathrm{HfO}_{2}$. a) Dependences of the average diameter $D$ of crystals on time $t$ for various growth rates $v$. b) Dependences of the crystalline phase fraction $x$ on $t^{2}$. Growth rates of the crystals: $v_{1}=0.035 \mu \mathrm{m} \cdot \mathrm{s}^{-1} ; v_{1}{ }^{\prime}=0.059 \mu \mathrm{m} \cdot \mathrm{s}^{-1} ; v_{2}=0.056 \mu \mathrm{m} \cdot \mathrm{s}^{-1} ; v_{2}{ }^{\prime}=$ $0.104 \mu \mathrm{m} \cdot \mathrm{s}^{-1} ; v_{3}=0.284 \mu \mathrm{m} \cdot \mathrm{s}^{-1} ; v_{3}^{\prime}=0.484 \mu \mathrm{m} \cdot \mathrm{s}^{-1}$.

was determined from the slope of the straight line to the axis of abscissas: $0.084 \mu \mathrm{m} \cdot \mathrm{s}^{-1} ; v_{2}=0.299 \mu \mathrm{m} \cdot \mathrm{s}^{-1}$.

The kinetic curves of crystallization for the given values of $v$ are plotted in Fig. $3 \mathrm{~b}$. They reflects the dependence of the fraction of the crystalline phase $x$ on time $t$, which has passed since the moment of the fixation of the onset of crystal formation. Since each crystal grew through the entire thickness of the film, the value of $x$ was determined as the ratio of the area occupied by the crystal to the total area of the object area analyzed in the microscope. The kinetic curves in coordinates $x-t^{2}$ are straight lines. This indicates the quadratic dependence of $x$ on $t$ :

$$
\begin{gathered}
x=0.002 s^{-2} t^{2}-0.011, \\
x=0.020 s^{-2} t^{2}+3.3 \cdot 10^{-4} .
\end{gathered}
$$

Expression (4a) corresponds to $v_{1}=$ $0.084 \mu \mathrm{m} \cdot \mathrm{s}^{-1}$, expression (4b) corresponds $v_{2}=0.299 \mu \mathrm{m} \cdot \mathrm{s}^{-1}$.

The two-stage phase transformation in the amorphous film starts with the nucleation and growth of the disk-shaped crystals of orthorhombic modification of $\mathrm{HfO}_{2}$ (crystals 2 in Fig. 1a and 1c). Then they split into domains with the orthorhombic and monoclinic modifications of $\mathrm{HfO}_{2}$. This splitting takes place when the diameter $D$ of disk-shaped crystals exceeds critical value of $D^{*}$. The dependences of the average diameter $D$ of the crystals on time $t$ for various growth rates are shown in Fig. 4a. While $D<D^{*}$, the disk-shaped crystals growth with a constant speed v. After splitting, the growth rate of the crystals appreciably increases. If before splitting the 
growth rate of the crystal is $v_{1}=$ $0.035 \mu \mathrm{m} \cdot \mathrm{s}^{-1}$, then after splitting its growth rate is $v_{1}{ }^{\prime}=0.059 \mu \mathrm{m} \cdot \mathrm{s}^{-1}$. Analogically $v_{2}=0.056 \mu \mathrm{m} \cdot \mathrm{s}^{-1}$ before splitting corresponds to $v_{2}^{\prime}=0.104 \mu \mathrm{m} \cdot \mathrm{s}^{-1}$ after splitting. And $v_{3}=0.284 \mu \mathrm{m} \cdot \mathrm{s}^{-1}$ before splitting corresponds to $v_{3}{ }^{\prime}=0.484 \mu \mathrm{m} \cdot \mathrm{s}^{-1}$ after splitting (Fig. 4a).

The values of $D^{*}, v$, and $v^{\prime}$, as well as the ratios $v^{\prime} / v$ for a series of crystallization sessions of amorphous hafnium dioxide are summarized in Table 1. According to the data in Table 1 after the crystal splitting its growth rate appreciably increases. There is no monotone dependence between $D^{*}$ and $v$, $v^{\prime}$ or $v^{\prime} / v$. The results of statistical treatment of measured $D^{*}$ are shown in the form of frequency $f$ histogram in Fig. 5. The $D^{*}$ distribution is characterized by the corrected root-mean-square deviation of $0.037 \mu \mathrm{m}$, the positive asymmetry of 0.57 . At the reliability level of 0.5 the diameter value $D^{*}=0.184 \pm 0.026 \mu \mathrm{m}$.

The kinetic crystallization curves (Fig. 4b) in coordinates $x-t^{2}$ have the form of straight lines with a kink at the point $t$, corresponding to the moment, when $D=D^{*}$ :

$$
\begin{aligned}
& x=\alpha t^{2}+\beta, \\
& x=\alpha^{\prime} t^{2}+\beta^{\prime} .
\end{aligned}
$$

Expression (5a) describes the dependence of $x(t)$ for $D<D^{*}$. Expression (5b) describes the dependence of $x(t)$ for $D>D^{*}$. Numerical values of $\alpha, \alpha^{\prime}, \beta$ and $\beta^{\prime}$ are given in Table 1.

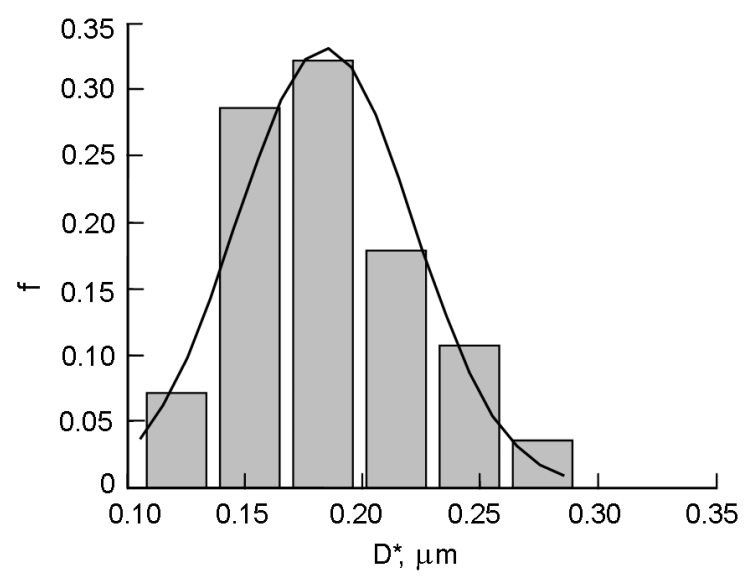

Fig. 5. Histogram of the relative frequencies $f$ of the critical diameters $D^{*}$ of $\mathrm{HfO}_{2}$ crystals and the curve, corresponding to the Gaussian distribution.

The presence of the one-stage (amorphous phase-monoclinic phase of $\mathrm{HfO}_{2}$ ) and the two-stage (amorphous phase-orthorhombic phase-monoclinic phase of $\mathrm{HfO}_{2}$ ) transformations at electron beam irradiation of the amorphous film is due to the polymorphism of hafnium dioxide. At room temperature (and up to $1923 \mathrm{~K}$ ), the monoclinic modification of $\mathrm{HfO}_{2}$ is stable. This explains its dominant presence at the final stage of the film crystallization and the existence of a size - phase effect, when the $\mathrm{HfO}_{2}$ crystal of the orthorhombic modification reaches the critical size $(\sim 0.2 \mu \mathrm{m})$ splits into domains with the monoclinic and orthorhombic crystal lattices. One of the vari-

Table 1. Parameters of a two-stage transformation during crystallization of amorphous film of $\mathrm{HfO}_{2} *$

\begin{tabular}{|c|c|c|c|c|c||}
\hline \hline$D^{*}, \mu \mathrm{m}$ & 0.143 & 0.160 & 0.235 & 0.266 & 0.294 \\
$\nu, \mu \mathrm{m} \cdot \mathrm{s}^{-1}$ & 0.057 & 0.029 & 0.035 & 0.284 & 0.056 \\
$v^{\prime}, \mu \mathrm{m} \cdot \mathrm{s}-1$ & 0.244 & 0.036 & 0.059 & 0.4804 & 40.1 \\
$\nu^{\prime} / \nu$ & 4.28 & 1.24 & 1.69 & 1.70 & 1.86 \\
$\alpha, \mathrm{s}^{-2}$ & 0.006 & 0.004 & 0.001 & 0.300 & 0.007 \\
$\beta$ & 0.002 & 0.007 & $0.3 \cdot 10^{-3}$ & 0.012 & 0.011 \\
$\alpha^{\prime}, \mathrm{s}^{-2}$ & 0.044 & 0.005 & 0.003 & 0.507 & 0.013 \\
$\beta^{\prime}$ & -0.180 & -0.015 & -0.058 & -0.088 & -0.106 \\
\hline
\end{tabular}

Notes. $D^{*}$ is the critical diameter of the $\mathrm{HfO}_{2}$ crystal at the moment of phase transformation from orthorhombic to monoclinic structure; $v$ is the growth rate of $\mathrm{HfO}_{2}$ crystal before phase transformation; $v^{\prime}$ is the growth rate of $\mathrm{HfO}_{2}$ crystal after phase transformation; $\alpha$ and $\beta$ are the coefficients in the ratio (5a) before phase transformation; $\alpha^{\prime}$ and $\beta^{\prime}$ are the coefficients in the ratio (5b) after phase transformation. 
Table 2. The arithmetic means of characteristic unit of length $<$ D0 $>$ and of relative length of crystallization $<$ ?0 $>$ for different types of polymorphic transformations of oxide films

\begin{tabular}{||c|c|c|c|c|c||}
\hline Parameter & $\begin{array}{c}\mathrm{DPC} \text { of } \mathrm{HfO}_{2} \\
\text { Laser } \\
\text { evaporation } \\
\text { (this work) }\end{array}$ & $\begin{array}{c}\mathrm{LPC} \text { of } \mathrm{V}_{2} \mathrm{O}_{3} \\
\text { Laser } \\
\text { evaporation } \\
{[16]}\end{array}$ & $\begin{array}{c}\mathrm{IPC} \text { of } \mathrm{V}_{2} \mathrm{O}_{3} \\
\text { Laser } \\
\text { evaporation } \\
{[16]}\end{array}$ & $\begin{array}{c}\text { IPC of } \mathrm{ZrO}_{2} \\
\text { Laser } \\
\text { evaporation } \\
{[15]}\end{array}$ & $\begin{array}{c}\mathrm{IPC} \mathrm{of}_{\mathrm{ZrO}} \\
\text { Ion-plasma } \\
\text { evaporation } \\
{[15]}\end{array}$ \\
\hline$<D_{0}>$ & $\mu \mathrm{m}$ & 1.59 & 2.24 & 0.68 & 0.46 \\
$<\delta_{0}>$ & 3075 & 4553 & 1024 & 904 & 118 \\
\hline
\end{tabular}

Notes. DPC - dendrite polymorphic crystallizations, LPC - layer polymorphic crystallizations, IPC - island polymorphic crystallizations.

ants of the conjugation of the orthorhombic and monoclinic lattices is given by (3).

According to the structural-morphological features, electron-beam crystallization of the amorphous hafnium dioxide corresponds to the dendrite polymorphic crystallization [12], when dendrite crystals are formed in the near-surface layer of the amorphous film with composition that corresponds to the composition of the amorphous film. Quantitative analysis of the features of the DPC of amorphous $\mathrm{HfO}_{2}$ films is advisable to be carried out in a similar way as the analysis of LPC and IPC of amorphous $\mathrm{V}_{2} \mathrm{O}_{3}$ and $\mathrm{ZrO}_{2}$ films [16]. By definition, a characteristic unit of time $t_{0}$ is the time, after which the volume of the amorphous phase decreases by a factor of $e$ (wherein $x=1-e^{-1}=0.632$ ). The characteristic unit of length $D_{0}$ is the crystal size at time $t_{0}\left(D_{0}=v t_{0}\right)[17]$.

At the one-stage crystallization of the film, according to (4a), the characteristic unit has length $D_{01}=1.51 \mu \mathrm{m}$, and according to (4b), the characteristic unit has length $D_{02}=1.68 \mu \mathrm{m}$. The values of $D_{01}$ and $D_{02}$ correspond to the crystal growth rates $v_{1}=0.084 \mu \mathrm{m} \cdot \mathrm{s}^{-1}$ and $v_{2}=$ $0.299 \mu \mathrm{m} \cdot \mathrm{s}^{-1}$. Their arithmetic mean $\left\langle D_{0}\right\rangle$ $=1.59 \mu \mathrm{m}$. Various branches of dendrites of $\mathrm{HfO}_{2}$ have different crystallographic orientations. Therefore, the relative length of crystallization $\delta_{0}$, introduced in $[15,16]$, should be defined as

$$
\delta_{0}=\frac{\left\langle D_{0}\right\rangle}{\Omega^{1 / 3}},
$$

where $\Omega$ is the volume of the unit cell of the monoclinic modification of $\mathrm{HfO}_{2}$, equal to $138.28 \AA^{3}$ [18].

According to (6) for the dendrite polymorphic crystallization of $\mathrm{HfO}_{2}$ the relative length of crystallization is $\delta_{0}=3075$. The arithmetic means $\left\langle D_{0}\right\rangle$ and $\left\langle\delta_{0}>\right.$ for different types of crystallization of $\mathrm{HfO}_{2}, \mathrm{~V}_{2} \mathrm{O}_{3}$ and $\mathrm{ZrO}_{2}$ are given in Table 2. According to these data, the values of $\delta_{0}$ for the DPC of $\mathrm{HfO}_{2}$ and for the LPC of $\mathrm{V}_{2} \mathrm{O}_{3}$ are very close (several thousand). At the same time, there is a significant difference between the data, characterizing the dendrite polymorphous crystallization of $\mathrm{HfO}_{2}$ and of its structural analogue $\mathrm{ZrO}_{2}$ with island polymorphic crystallization, for which the value of $\delta_{0}$ is several hundred.

The increasing of density of the film matter during crystallization of amorphous $\mathrm{ZrO}_{2}$ is much higher than in the case of amorphous $\mathrm{HfO}_{2}$. For $\mathrm{ZrO}_{2} \quad \gamma=$ 10.27 $\pm 2.14 \%$ [20], and for $\mathrm{HfO}_{2}$ (present work) $\gamma=2.51 \pm 1.66 \%$. According to [5] with increasing temperature from the room temperature (amorphous $\mathrm{HfO}_{2}$ ) to $750^{\circ} \mathrm{C}$ (crystalline $\mathrm{HfO}_{2}$ ) the density of matter rises from $8.96 \mathrm{~g} \cdot \mathrm{cm}^{-3}$ to $9.40 \mathrm{~g} \cdot \mathrm{cm}^{-3}$. For this case, according to (2), $\gamma=4.91 \%$, which is slightly higher than the upper limit of the confidence interval $4.17 \%$. For monoclinic phase of $\mathrm{HfO}_{2}$ the density of matter is $\rho_{c}=9.68 \mathrm{~g} \cdot \mathrm{cm}^{-3}$ [19]. For the amorphous phase of $\mathrm{HfO}_{2}$ the density of matter is $\rho_{a}=9.39 \mathrm{~g} \cdot \mathrm{cm}^{-3}$ [20]. In this case, according to (2), there is $\gamma=3.09 \%$. This value of $\gamma$ falls within the confidence interval from $0.85 \%$ to $4.17 \%$, that is established in this paper.

\section{Conclusions}

Amorphous films of $\mathrm{HfO}_{2}$ were prepared with laser ablation of $\mathrm{Hf}$ in oxygen atmosphere at pressure of about $0.13 \mathrm{~Pa}$ on the substrates at the room temperature. Electron beam heating of the amorphous film initiates in it the dendrite polymorphic crystallization, which can be either singlestage or two-stage in nature. In the first 
case, dendrites crystals of the monoclinic modification of $\mathrm{HfO}_{2}$ are generated and grow at a constant tangential velocity. In the second case, at the initial stage, discshaped crystals of the orthorhombic modification of $\mathrm{HfO}_{2}$ are growing. When their diameters exceed the critical value $(\sim 0.2 \mu \mathrm{m})$, the formation of domains with the monoclinic crystal lattice takes place in them. This is accompanied with a marked increasing in the growth rate and with the formation of the dendrite morphology. The crystallization kinetic parameters are determined and it is shown, that the quadratic dependence of the fraction of the crystalline phase on time is fulfilled. The average value of the relative length for the dendrite polymorphic crystallization is 3075 . Crystallization of the amorphous $\mathrm{HfO}_{2}$ is accompanied with densifying of the film material. The relative change in the density during its crystallization is about $2.5 \%$.

\section{References}

1. Nai-Wen Pi, Minghui Zhang, Jiechao Jiang et al., Thin Solid Films, 619, 239 (2016).

2. Tsung-Ju Chen, Chin-Lung Kuo, J.Appl.Phys, 110, 064105 (2011).

3. J.Lu, J.Aarik, J.Sundqvist et al., J.Cryst. Growth, 273, 510 (2005).

4. Y.-S.Lin, R.Puthenkovilakam, J.P.Chang, Appl. Phys. Lett. 81, 2041 (2002).
5. M.Modreanu, J.Sancho-Parramon, D.O'Connell et al., Mater.Sci.Eng. B, 118, 127 (2005).

6. M.A.Pugachevskii, V.I.Panfilov, Techn.Phys. Lett., 41, 291 (2015).

7. A.G.Bagmut, I.A.Bagmut, V.A.Zhuchkov, M.O.Shevchenko, Techn.Phys. Lett. , 38, 22 (2012).

8. A.G.Bagmut, I.A.Bagmut, V.A.Zhuchkov, M.O.Shevchenko, Techn.Phys., 57, 856 (2012).

9. B.J.Kooi, W.M.G.Groot, J.Th.M.De Hosson, J.Appl.Phys., 95, 924 (2004).

10. A.G.Bagmut, Electron Microscopy of Films Deposited by Laser Evaporation. Monograph, NTU "KhPI", Kharkiv (2014) [in Russian].

11. A.G.Bagmut, Functional Materials, 19, 370 (2012).

12. A.G.Bagmut, Techn.Phys.Lett., $\quad 38,488$ (2012).

13. A.G.Bagmut, A.V.Taran, J.Adv.Microsc. Res., 8, 57 (2013).

14. A.G.Bagmut, S.N.Grigorov, V.Yu.Kolosov et al., Functional Materials, 10, 687 (2003).

15. A.G.Bagmut, V.M.Beresnev, Phys. Solid State, 59, 151 (2017).

16. A.G.Bagmut, Phys. Solid State, 59, 1225 (2017).

17. A.N.Kolmogorov, Izv.Akad.Nauk SSSR, 3, 355 (1937).

18. JCPDS Powder Diffraction File Card No. 431017 (International Centre for Diffraction Data, Swarthmore, PA, 1996).

19. S.V.Ushakov, A.Navrotsky, Y.Yang et al., Phys. Stat. Solidi (b), 241, 2268 (2004).

20. D.Ceresoli, D.Vanderbilt, Phys.Rev.B, 74, 125108 (2006). 